\title{
Partial purification and properties of carminomycin 4-O-methyltransferase from Streptomyces sp. strain C5
}

\author{
Neal C. Connors $\dagger$ and William R. Strohl* \\ Department of Microbiology, The Ohio State University, 484 West 12th Avenue, Columbus, Ohio 43210, USA
}

(Received 22 September 1992; revised 17 December 1992; accepted 25 January 1993)

\begin{abstract}
A methyltransferase that acts on carminomycin and 13-dihydrocarminomycin, and that is postulated to be the terminal enzyme in the daunomycin biosynthesis pathway, was purified to near-homogeneity from the daunomycinand baumycin-producing Streptomyces sp. strain C5. The enzyme was obtained in approximately 5\% yield with a purification of 114-fold in specific activity over the sample precipitated with $30-50 \%$ ammonium sulphate. Polyacrylamide gel electrophoresis under denaturing conditions indicated a subunit $M_{\mathrm{r}}$ of about 41000 . The enzyme was shown by gel filtration chromatography to have an $M_{\mathrm{r}}$ of approximately 166000 , suggesting that it is a homotetramer. Kinetic analysis indicated an affinity for $S$-adenosyl-L-methionine typical of antibiotic methyltransferases; the enzyme had a slightly higher affinity for carminomycin than for 13-dihydrocarminomycin. The reaction product from methylation of carminomycin was confirmed by chromatography and mass spectral analysis to be daunomycin. The purified enzyme did not catalyse methylation of the aglycones carminomycinone or 13-dihydrocarminomycinone. $S$-Adenosyl-L-homocysteine inhibited the methyltransferase, whereas homocysteine, adenosine, adenine, $\varepsilon$-rhodomycinone, daunomycin, and daunomycinone showed little or no inhibitory activity.
\end{abstract}

\section{Introduction}

We recently postulated a partial pathway for the biosynthesis of daunomycin by Streptomyces sp. strain C5 based on results obtained with blocked mutants (Bartel et al., 1990), in vitro bioconversion reactions (Connors et al., 1990a), and the discovery of an enzyme capable of methylating carminomycin (Connors et al., $1990 \mathrm{~b}$ ). The first half of the pathway, i.e. the formation of $\varepsilon$-rhodomycinone from the theoretical polyketide precursor, has now been characterized in relative detail (Eckardt \& Wagner, 1988; Bartel et al., 1990; Connors et $a l ., 1990 a$; Strohl \& Connors, 1992). On the other hand, except for our characterization of TDP-D-glucose 4,6dehydratase, the first enzyme in TDP-daunosamine biosynthesis (Thompson et al., 1992), and our pre-

\footnotetext{
*Author for correspondence. Tel. (614) 2921919 ; fax (614) 292 1538; email: wstrohl@magnus.acs.ohio-state.edu.

$\dagger$ Present address: Merck, Sharp and Dohme Research Labs, PO Box 2000, R810-202, Rahway, NJ 07065, USA.
}

Abbreviations: AdoHcy, $S$-adenosyl-L-homocysteine; AdoMet, $S$ adenosine-L-methionine; CMT, carminomycin 4- $O$-methyltransferase; FPLC, fast protein liquid chromatography; HPT, hydroxylapatite. liminary description of carminomycin methyltransferase (CMT) activity (Connors et al., 1990 b), the enzymic reactions involved in glycosylation and the conversion of $\varepsilon$-rhodomycinone to daunomycin remain largely uncharacterized. We previously found that a methyltransferase activity in crude cell extracts of several daunomycin-producing streptomycetes methylated carminomycin and 13-dihydrocarminomycin (Fig. 1), but no other glycones or aglycones tested, suggesting that conversion of carminomycin to daunomycin is the terminal reaction in daunomycin biosynthesis (Connors et al., $1990 \mathrm{~b}$ ). Here we report the partial purification and characteristics of an enzyme from Streptomyces sp. strain $\mathrm{C} 5$ that catalyses the 4-O-methylation of carminomycin and 13-dihydrocarminomycin to daunomycin and 13dihydrodaunomycin, respectively.

\section{Methods}

Organism and growth conditions. Streptomyces sp. strain C5 (Bartel et al., 1990) was obtained from the Frederick Cancer Research Center, Frederick, MD, USA. NDYE medium was used for seed cultures as well as for growth of the culture in stirred-tank fermenters. NDYE medium contained (per litre): glucose, $22.5 \mathrm{~g}$ (autoclaved and added separately); yeast extract, $5 \mathrm{~g}$; $\mathrm{NaNO}_{3}, 4.28 \mathrm{~g}$; MOPS, $4 \cdot 18 \mathrm{~g} ; \mathrm{K}_{2} \mathrm{HPO}_{4}$, $0.174 \mathrm{~g} ; \mathrm{MgSO}_{4}, 0.060 \mathrm{~g}$; and $20 \times$ trace element solution (Dekleva et 


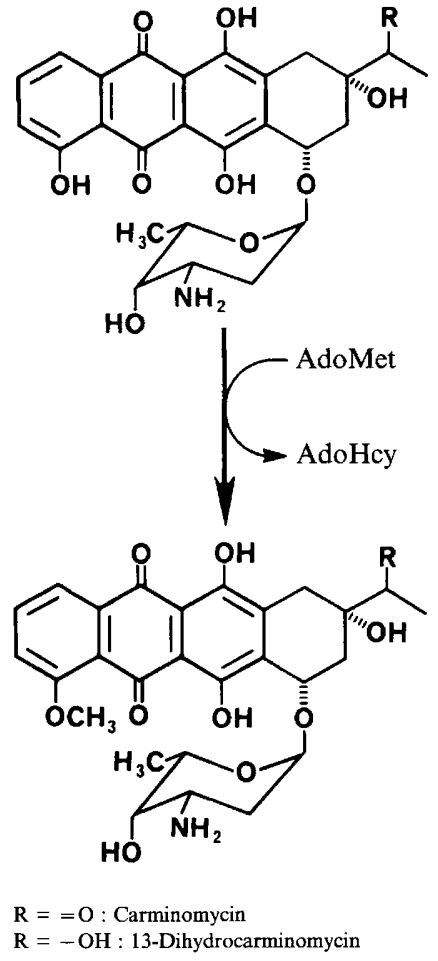

Fig. 1. AdoMet-dependent CMT-catalysed methylation of carminomycin and 13-dihydrocarminomycin to daunomycin and 13-dihydrodaunomycin, respectively.

al., 1985), $1 \mathrm{ml}$. A dense spore suspension $(100 \mu \mathrm{l})$ was used to inoculate a $250 \mathrm{ml}$ culture flask containing $50 \mathrm{ml}$ NDYE medium and a coiled spring (Dekleva et al., 1985). This primary seed culture was incubated for $2 \mathrm{~d}$ with rotary shaking ( 250 r.p.m.) at $30^{\circ} \mathrm{C}$, and $25 \mathrm{ml}$ were used to inoculate a 2 litre flask containing $500 \mathrm{ml} \mathrm{NDYE}$ and a coiled spring. This secondary seed culture was incubated as described above for $1 \mathrm{~d}$ and used to inoculate a 14 litre stirred-tank fermenter (New Brunswick) containing 10 litres NDYE. In fermentations for the purification of CMT, air flow was maintained at $101 \mathrm{~min}^{-1}$, agitation was constant at 250 r.p.m., the temperature was $30^{\circ} \mathrm{C}$, and the $\mathrm{pH}$ (initially 7.2 ) was not controlled. After $48 \mathrm{~h}$ of growth, the mycelium (approximately $35 \mathrm{~g}$ wet wt per litre of culture) was concentrated using a Pellicon tangential flow filtration apparatus (Millipore). The concentrated biomass was harvested by centrifugation $(10000 \mathrm{~g}, 15 \mathrm{~min})$, resuspended in $0.05 \mathrm{M}$-Tris/ $\mathrm{HCl}(\mathrm{pH} 8.0)$ and centrifuged a second time as indicated. The washed mycelial pellets were stored at $-70^{\circ} \mathrm{C}$ until needed.

Assay for CMT activity. The standard assay contained (in $0.10 \mathrm{ml}$ ): anthracycline substrate, $40 \mathrm{nmol} ; S$-adenosyl-[methyl $\left.{ }^{3} \mathrm{H}\right]-\mathrm{L}-$ methionine $\left[{ }^{3} \mathrm{H}\right.$-AdoMet; $73 \mathrm{Ci} \mathrm{mmol}^{-1}\left(2701 \mathrm{GBq} \mathrm{mmol}^{-1}\right)$ (New England Nuclear) diluted to $6 \mu \mathrm{Ci} \mu \mathrm{mol}^{-1}\left(222 \mathrm{kBq} \mu \mathrm{mol}^{-1}\right)$ with non-radioactive $S$-adenosyl-L-methionine], $100 \mathrm{nmol}(0.6 \mu \mathrm{Ci}$ of radioactivity); enzyme preparation, $0.005-0.025 \mathrm{ml}$ (typically $10-50 \mu \mathrm{g}$ protein); the volume was adjusted to $0.10 \mathrm{ml}$ with $0.05 \mathrm{M}$-Tris $/ \mathrm{HCl}$ buffer, $\mathrm{pH} 8.0$. The reaction mixture was incubated at $37^{\circ} \mathrm{C}$ for $15 \mathrm{~min}$, after which methylated anthracyclines were extracted by vigorous agitation with 5 vols chloroform/methanol $(9: 1, \mathrm{v} / \mathrm{v})$. After centrifugation to promote phase separation, the organic phase was allowed to air dry and its radioactivity measured (ScintiVerse E, Fisher Scientific) using a Beckman LS6800 scintillation counter. For every sample assayed, a control reaction was carried out in the absence of anthracycline substrate to correct for chloroform/methanol-extractable background radioactivity. This background activity was relatively constant and approximated to the amount of radioactivity recovered when boiled extracts replaced active extracts. Protein was measured by the dyebinding assay of Bradford (1976) using reagent purchased from BioRad.

Analysis of products formed from methyltransferase reaction. Reactions carried out for the separation and determination of products by TLC and autoradiography, as well as for monitoring the early steps of CMT purification, contained $S$-adenosyl- $\left[\right.$ methyl $\left.-{ }^{14} \mathrm{C}\right]-\mathrm{L}$-methionine $\left[{ }^{14} \mathrm{C}\right.$-AdoMet; $0.04 \mu \mathrm{Ci}(1.48 \mathrm{kBq})$ per reaction, $43 \mathrm{mCi} \mathrm{mmol}^{-1}$ (1591 MBq $\mathrm{mmol}^{-1}$ ); New England Nuclear] instead of diluted ${ }^{3} \mathrm{H}$ AdoMet. Reaction mixtures to be analysed by TLC were solventextracted as described previously (Connors et al., 1990 b), air dried and then applied in $10 \mu \mathrm{l}$ chloroform to a $0.25 \mathrm{~mm}$ layer of silica gel. The TLC plates (Whatman) were developed with chloroform/methanol/ glacial acetic acid $/ \mathrm{H}_{2} \mathrm{O}(15: 5: 1: 1$, by vol.) and exposed to X-ray film (Kodak X-Omat AR) for 3-5 d; the reaction products were compared to authentic standards by co-chromatography or in parallel.

For mass spectrometry-mass spectrometry (MS-MS), $150 \mu \mathrm{l}(55 \mu \mathrm{g})$ of the enzyme from the Mono Q-Tris step was incubated for $1 \mathrm{~h}$ $\left(30^{\circ} \mathrm{C}\right)$ with $20 \mu \mathrm{l} 10 \mathrm{mM}$ unlabelled AdoMet and $15 \mu \mathrm{l} 8.0 \mathrm{mM}$ carminomycin. The mixture was then extracted with chloroform/ methanol and the air-dried organic phase was used for mass spectral analysis.

Buffers. The specific buffers used were: buffer $1,0.05 \mathrm{M}-\mathrm{Tris} / \mathrm{HCl}$ (pH 8.0) containing 1 mM-DTT; buffer $2,0.05 \mathrm{M}$-Tris $/ \mathrm{HCl}(\mathrm{pH} \mathrm{8.0)}$ containing $1 \mathrm{~mm}-\mathrm{DTT}$ and $10 \%(\mathrm{v} / \mathrm{v})$ glycerol; buffer $3,0.01 \mathrm{M}-$ potassium phosphate (pH 7.0) containing $1 \mathrm{~mm}$-DTT and $10 \%$ glycerol; buffer 4, 0.05 M-potassium phosphate ( $\mathrm{pH} \mathrm{8.0)} \mathrm{containing}$ $1 \mathrm{~mm}-\mathrm{DTT}$ and $10 \%(\mathrm{v} / \mathrm{v})$ glycerol; and buffer $5,0.05 \mathrm{M}-\mathrm{Tris} / \mathrm{HCl}$ (pH 8.0) containing $1 \mathrm{~mm}-\mathrm{DTT}, 10 \%(\mathrm{v} / \mathrm{v})$ glycerol, and $0 \cdot 1 \mathrm{M}-\mathrm{KCl}$.

Purification of the methyltransferase. All enzyme purification procedures were carried out at $4{ }^{\circ} \mathrm{C}$. Frozen mycelium (150-200 g wet wt) was thawed, resuspended in buffer 1 and disrupted in an automated French pressure cell (American Instrument Co) at 15000-16000 p.s.i. The supernatant from centrifugation at $20000 \mathrm{~g}$ for $30 \mathrm{~min}$ was fractionated by the sequential addition of solid ammonium sulphate to $30 \%$ and then $50 \%$ saturation. Essentially $100 \%$ of the CMT activity was soluble at $30 \%$ but precipitated at $50 \%$ saturation. The precipitate was dissolved in a small volume of buffer 2 and was dialysed overnight against the same buffer.

The dialysed protein solution was chromatographed on a DEAESepharose column $(16.5 \times 5 \mathrm{~cm})$ previously equilibrated with buffer 2 . After adsorption of the proteins, the column was washed with $500 \mathrm{ml}$ buffer 2, and the adsorbed proteins were eluted with a $300 \mathrm{ml}$ linear gradient of $0-0.45 \mathrm{M}-\mathrm{KCl}$ in buffer 2 . The flow rate was $40 \mathrm{ml} \mathrm{h}^{-1}$ and $4 \mathrm{ml}$ fractions were collected. Fractions containing CMT activity were combined, and the proteins were precipitated with solid ammonium sulphate (to $60 \%$ saturation), dissolved in a small volume of buffer 3 , and dialysed against two changes of 2 litres each of buffer 3 . Hydroxylapatite resin (HPT, BioRad), previously equilibrated with buffer 3 and recovered by centrifugation, was mixed with the dialysed protein solution and the mixture was incubated at $4{ }^{\circ} \mathrm{C}$ for $30 \mathrm{~min}$. After incubation, the HPT resin was removed from the slurry by two rounds of centrifugation at $10000 \mathrm{~g}(10 \mathrm{~min}$ each). The CMT activity in the HPT supernatant was concentrated by ammonium sulphate precipitation as described above.

The precipitated proteins were dissolved in a small volume of buffer 4 and dialysed against two changes of 2 litres each of buffer 4 . The dialysed protein solution was fractionated in $2 \mathrm{ml}$ aliquots by chromatography on a Mono Q HR 5/5 anion-exchange FPLC column (Pharmacia) using phosphate buffer as described by Vara \& Hutchinson 
(1988). The column with adsorbed proteins was first washed with $7 \mathrm{ml}$ buffer 4 ; then the adsorbed proteins were eluted with a $25 \mathrm{ml}$ linear gradient of $0-0.25 \mathrm{M}-\mathrm{KCl}$ in buffer 4 . The flow rate was $1 \mathrm{ml} \mathrm{min}^{-1}$ and $1 \mathrm{ml}$ fractions were collected.

The fractions from Mono Q-phosphate chromatography containing CMT activity were concentrated by ultrafiltration using a Centricon 10 (Amicon) and $100 \mu \mathrm{l}$ aliquots were consecutively fractionated by chromatography through a TSK-400 (BioRad) HPLC gel-filtration column $(300 \times 7.8 \mathrm{~mm})$ using a mobile phase of buffer 5 as previously described (Thompson et al., 1992). The flow rate was $0.5 \mathrm{ml} \mathrm{min}{ }^{-1}$ and $0.25 \mathrm{ml}$ fractions were collected.

Fractions from TSK-400 chromatography were pooled and concentrated to $2 \mathrm{ml}$ using a Centricon 10 ; then the buffer was exchanged by gel-filtration using an Econo-Pac 10DG desalting column (BioRad) previously equilibrated with buffer 2 . The desalted protein solution was applied to a Mono Q HR 5/5 anion-exchange column and washed with $3 \mathrm{ml}$ buffer 2; bound proteins were eluted with a $20 \mathrm{ml}$ linear gradient of $0-0.35 \mathrm{M}-\mathrm{KCl}$ in buffer 2 . The flow rate was $1 \mathrm{ml} \mathrm{min}-1$ and $1 \mathrm{ml}$ fractions were collected.

Electrophoresis. SDS-PAGE was as described by Laemmli (1970). When necessary, proteins were precipitated with chloroform and methanol as described by Pohl (1990) and sample buffer was added to the air-dried protein. Electrophoresis was carried out at 25-30 mA per gel using the Mini-Protean II system (BioRad). Proteins in the gels were detected by silver staining as described by Morrissey (1981).

For the detection of CMT activity from electrophoretically separated proteins, non-denaturing PAGE was carried out. A $6 \%(\mathrm{w} / \mathrm{v})$ resolving gel (without SDS), into which sample wells were cast directly, was preelectrophoresed for $30 \mathrm{~min}$ as above to remove reactive molecules involved in gel polymerization. Samples $(10 \mu \mathrm{l}$ each, and not diluted with sample buffer) were loaded into the wells and electrophoresis was carried out at $25 \mathrm{~mA}$. Proteins in a marker sample lane were detected by silver staining as described above and were used to locate corresponding proteins in adjacent lanes. Areas of the gel containing proteins of interest were excised and the gel slices were used directly in the CMT assay without elution of the proteins. A gel slice containing no protein was used as a control. When gel slices were used in the CMT assay, the reaction volume was increased to $0.25 \mathrm{ml}$ by the addition of assay buffer to offset the increase in $\mathrm{pH}$ brought about by the gel slice (pH 8.8).

Determination of the native $M_{r}$ of $C M T$. Two hundred microlitres (5-6 mg total protein) of partially purified CMT (through the DEAESepharose step) were applied to a Superose 6 FPLC gel filtration column which had been equilibrated with buffer 5 . The elution volume of peak CMT activity was used to interpolate the $M_{\mathrm{r}}$ of native CMT from linear plot of the logarithm of native $M_{\mathrm{r}}$ as a function of elution volume for the proteins used as size standards.

Kinetics and substrate and inhibitor specificity of CMT. Apparent $K_{\mathrm{m}}$ $\left(K_{\mathrm{m}}^{\prime}\right)$ was estimated for carminomycin and 13-dihydrocarminomycin as the anthracycline substrates, and for AdoMet as the co-substrate, using a preparation of CMT purified approximately 100 -fold over the ammonium sulphate step (purification data not shown). For the kinetics of the enzyme as a function of anthracycline concentration, AdoMet was in excess (1 mM) and the concentration of anthracycline was varied from $0 \cdot 10$ to $10 \mu \mathrm{M}$. For the kinetics of the enzyme as a function of AdoMet concentration, carminomycin was in excess $(400 \mu \mathrm{M})$ and the concentration of AdoMet was varied between 10 and $500 \mu \mathrm{M}$. The kinetic constants were determined in duplicate at two different protein concentrations using Lineweaver-Burk and EadieHofstee plots.

Inhibition reactions were carried out in duplicate with carminomycin and AdoMet at final concentrations of 10 and $250 \mu \mathrm{M}$, respectively. These concentrations were approximately 10 -fold higher than the $K_{\mathrm{m}}^{\prime}$ values determined for each substrate. This allowed for the evaluation of candidate inhibitor concentrations likely to resemble physiological conditions; however, the intracellular concentration in Streptomyces sp. strain C5 of each inhibitor tested is unknown. Adenosine, adenine, methionine and homocysteine were added to the reaction mixtures at final concentrations of $250 \mu \mathrm{M}$. Anthracyclinones and anthracyclines were added at $10 \mu \mathrm{M}$, and AdoHcy was at a final concentration of $25 \mu \mathrm{M}$.

Reproducibility of results. Unless otherwise stated, all experiments were carried out at least in duplicate and the results are means of those data. All purification steps were performed at least three times. The data given are for a representative purification scheme.

\section{Results}

\section{Analysis of CMT activity}

We previously found, in cell extracts of Streptomyces sp. strain C5 and other daunomycin-producing streptomycetes, an enzyme capable of methylating carminomycin to a product that co-migrated with daunomycin (Connors et al., 1990b). In those studies, AdoMet of very high specific activity $\left[46 \mathrm{Ci}\left(\mathrm{mol}^{14} \mathrm{C}-\mathrm{AdoMet}\right)^{-1}\right]$ was used to detect the activity in crude cell extracts (Connors $e$ t al., $1990 \mathrm{~b}$ ). This assay is extremely sensitive for detecting CMT activity but, from a kinetic standpoint, is firstorder with respect to AdoMet concentration. As a result, it was necessary to increase the concentration of AdoMet. The consequent reduction in specific radioactivity resulted in reduced sensitivity, bringing CMT activity in crude extracts of Streptomyces sp. strain C5 below the detectable level (determined to be $0.01 \mathrm{nmol} \mathrm{min}{ }^{-1}$ ), even when high protein concentrations were used. Therefore, the product from the first purification step, precipitation with ammonium sulphate, was assayed using the high specific activity label; its identity was confirmed by TLC and autoradiography. CMT activity in fermentation cultures of Streptomyces sp. strain C5 was found to be maximal at a period of about 48-72 h (data not shown). Therefore, the enzyme was purified from 48 -h-old cultures.

CMT activity was defined as carminomycin- and ${ }^{3} \mathrm{H}$ AdoMet-specific, chloroform/methanol-partitionable radioactivity. Using the optimized assay, CMT activity was linear over a 5-20 min interval (using 35 or $70 \mu \mathrm{g}$ protein in the assay) and with 8-70 $\mu \mathrm{g}$ protein (using a 15 min assay; data not shown). In control experiments, the efficiency of daunomycin extraction from the reaction mixture was determined to be greater than $95 \%$. No demonstrable colour quenching of radioactivity was observed, even with carminomycin concentrations up to $40 \mu \mathrm{M}$ (data not shown).

Several preliminary investigations were carried out using CMT purified by ammonium sulphate precipitation and DEAE-Sepharose fractionation (approximate purification was 16-fold over crude cell extracts as 
Table 1. Purification of CMT from Streptomyces sp. strain C5

\begin{tabular}{lccccc}
\hline \hline $\begin{array}{c}\text { Purification } \\
\text { step }\end{array}$ & $\begin{array}{c}\text { Total } \\
\text { protein } \\
(\mathrm{mg})\end{array}$ & $\begin{array}{c}\text { Total } \\
\text { activity } \\
\text { (units }\end{array}$ & $\begin{array}{c}\text { Specific } \\
\text { activity } \\
\left.\text { (units } \mathrm{mg}^{-1}\right)\end{array}$ & $\begin{array}{c}\text { Yield } \\
(\%)\end{array}$ & $\begin{array}{c}\text { Purification } \\
\text { (-fold) }\end{array}$ \\
\hline Cell extract & 1293 & - & - & - & - \\
Ammonium sulphate & 889 & 151 & $0 \cdot 17$ & $100 \dagger$ & $1 \cdot 0 \dagger$ \\
DEAE-Sepharose & 238 & 171 & $0 \cdot 72$ & 113 & $4 \cdot 2$ \\
Hydroxylapatite & 112 & 137 & $1 \cdot 22$ & 91 & $7 \cdot 2$ \\
$\begin{array}{l}\text { Mono Q FPLC } \\
\text { (phosphate buffer) }\end{array}$ & $13 \cdot 5$ & $70 \cdot 0$ & $5 \cdot 18$ & 46 & $30 \cdot 0$ \\
TSK-400 HPLC & $2 \cdot 2$ & $41 \cdot 0$ & $18 \cdot 5$ & 27 & 109 \\
Mono Q FPLC & $0 \cdot 38$ & $7 \cdot 4$ & $19 \cdot 4$ & 5 & 114 \\
(Tris/HCl buffer) & & & & & \\
\hline \hline
\end{tabular}

*A unit of activity is defined as the amount of enzyme required to incorporate 1 carminomycin-specific nmol of $\left[{ }^{3} \mathrm{H}\right]$ methyl groups from AdoMet per min under the reaction conditions described in the text.

$\dagger$ CMT activity in crude cell extract is below the detection limit of the optimized assay. Therefore, percentage yield and purification factor based on activity in the ammonium sulphate fractionation step are assigned the values 100 and 1 , respectively.

determined using high specific activity assays). The optimum temperature for activity of the partially purified CMT was $37^{\circ} \mathrm{C}$, with about a $10 \%$ decrease in activity at 30 or $45^{\circ} \mathrm{C}$. The optimal $\mathrm{pH}$ for activity of the partially purified enzyme was 8.0 , with $\mathrm{pH}$ values of 7.5 and 7.0 resulting in $60 \%$ and $80 \%$ decreases in activity, respectively (data not shown). No $\mathrm{pH}$ values above 8.0 were evaluated due to the inherent instability of AdoMet at alkaline $\mathrm{pH}$. While a $\mathrm{pH}$ of 8.0 was necessary for optimal activity, the enzyme was stable at a $\mathrm{pH}$ of $7 \cdot 0$, which facilitated the use of hydroxylapatite chromatography. No divalent cation requirement could be demonstrated for the partially purified enzyme, and the enzyme was $100 \%$ active after exhaustive dialysis against buffers of different composition and $\mathrm{pH}$ (between 7.0 and $8 \cdot 0)$.

\section{Stability of CMT}

When mycelia of Streptomyces sp. strain C5 were harvested, washed with $50 \mathrm{~mm}-\mathrm{Tris} / \mathrm{HCl}, \mathrm{pH} 8.0$, and frozen at $-70^{\circ} \mathrm{C}$, there was no apparent loss in the CMT activity after several weeks. The presence of DTT and glycerol stabilized CMT. In their absence, all activity was lost over 3-5 d at $4{ }^{\circ} \mathrm{C}$. In the presence of $1 \mathrm{mM}$-DTT and $10 \%(\mathrm{v} / \mathrm{v})$ glycerol, CMT activity decreased only $15 \%$ after $14 \mathrm{~d}$ at $4{ }^{\circ} \mathrm{C}$.

\section{Purification of CMT from Streptomyces sp. strain C5}

The purification of CMT is summarized in Table 1. Attempts to stimulate activity in crude extracts by dialysis, desalting by gel filtration through an Econo-Pac 10DG column, or treatment with high salt (up to $2 \mathrm{M}$ $\mathrm{KCl}$ or ammonium sulphate) followed by dialysis failed to yield a cell extract preparation with detectable CMT activity using the standard assay. Therefore, the presence of CMT activity was monitored during the first steps of purification using TLC-autoradiography.

Ammonium sulphate fractionation repeatedly resulted in an approximately fourfold purification as determined using the high specific activity assays, and the enzyme resulting from ammonium sulphate fractionation followed by dialysis was detectable using the standard assay (Table 1). It is not clear whether detectable activity after the ammonium sulphate step is the result of the removal of a competing activity or an inhibitor or the concentration of a small amount of CMT activity. Since this was the first purification step at which CMT activity could be quantified using the standard assay, this specific activity was used for subsequent calculations, and percentage yield and purification factor were assigned values of 100 and 1 , respectively (Table 1 ). These assignments result in an over-estimation of yield and an under-estimation of purification; however, inclusion of the approximately fourfold purification by the ammonium sulphate precipitation is not justified because the high specific activity assay used for that step was not optimized.

CMT was eluted from DEAE-Sepharose between $0 \cdot 19$ and $0.23 \mathrm{M}-\mathrm{KCl}$ (Fig. 2a) with a fourfold purification over the previous step (Table 1) and a recovery of 171 units of activity; the yield of CMT increased approximately $13 \%$ after DEAE-Sepharose fractionation. This increase indicates removal of an inhibitory or competing activity that could be a factor in the inability to detect CMT activity in cell extracts. In several preliminary experiments, an inhibitory (or competing) factor resided in fractions eluting from DEAE-Sepharose at $0 \cdot 1 \mathrm{M}-\mathrm{KCl}$ (B. Monte de Ramos, A. Rozic, N. C. Connors \& W. R. Strohl, unpublished). Other DEAE-Sepharose fractionations gave higher increases in CMT yield, depending on 

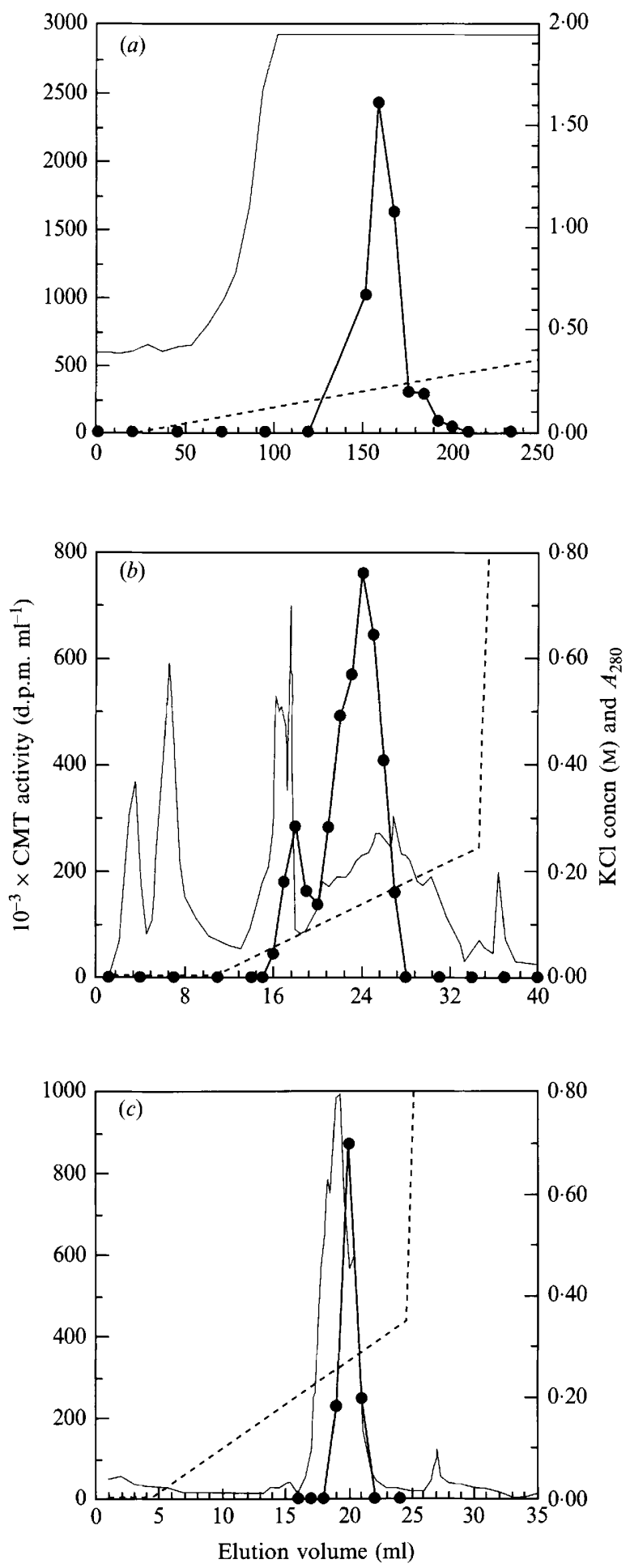

Fig. 2. Chromatographic purification of the methyltransferase. Chromatographic conditions are described in Methods. ----, $\mathrm{KCl}$ gradient; $\longrightarrow, A_{280} ;-1-\mathrm{CMT}$ activity. (a) DEAE-Sepharose column chromatography using buffer 2 . CMT was eluted with a linear gradient of $0-0.45 \mathrm{M}-\mathrm{KCl}$ in buffer 2. (b) Mono Q HR $5 / 5$ anion-exchange chromatography using phosphate buffer. A linear gradient of $0-0.25 \mathrm{M}-$ $\mathrm{KCl}$ in buffer 4 was used to elute CMT. (c) Mono Q HR 5/5 anionexchange chromatography using Tris $/ \mathrm{HCl}$ buffer. A linear gradient of $0-0.35 \mathrm{M}-\mathrm{KCl}$ in buffer 2 was used to elute CMT. the amount of protein adsorbed to the resin, a factor which could possibly influence the adsorption of a loosely bound effector molecule (data not shown).

CMT was not included in the $50-60 \%$ of total protein adsorbed to the HPT resin, affording a 1.5-2-fold purification over DEAE-Sepharose with a greater than $90 \%$ recovery (Table 1 ). HPT fractionation reduced the amount of total protein, facilitating the use of the lowcapacity Mono Q HR 5/5 anion-exchange procedure as the next step. Fractionation of the enzyme with Mono $Q$ HR FPLC-phosphate buffer (Vara \& Hutchinson, 1988) resulted in the reproducible resolution of two peaks containing CMT activity. The first, representing about $10 \%$ of the total activity, eluted at $0.06-0.08 \mathrm{M}-\mathrm{KCl}$ while the second, containing about $90 \%$ of the total CMT activity, eluted at $0 \cdot 11-0 \cdot 16 \mathrm{M}-\mathrm{KCl}$ (Fig. $2 b$ ). Only the major fraction was used further in the purification shown in Table 1 and its specific activity was increased fourfold over the previous step. In separate experiments the minor CMT activity eluted and migrated with the major fraction through the rest of the purification protocol. However, only the major fraction could be purified in any appreciable yield and it is the only CMT activity represented in Table 1 . A 3.6-fold purification with a $58 \%$ recovery of the enzyme was achieved by HPLC gel-filtration using a TSK-400 column. At this point, CMT was purified 109-fold over the product of ammonium sulphate fractionation, with a $27 \%$ recovery (Table 1). Highly purified CMT was obtained by Mono Q HR 5/5 anion-exchange chromatography using Tris/ $\mathrm{HCl}$ buffer and a linear $0-0.35 \mathrm{M}-\mathrm{KCl}$ gradient. CMT eluted as a sharp peak ( 7.4 total units) at $0.26 \mathrm{M}-\mathrm{KCl}$ (Fig. 2c) and was purified 114-fold over the ammonium sulphate fractionation products with $5 \%$ overall yield of activity. Approximately $0.4 \mathrm{mg}$ protein was obtained from $150 \mathrm{~g}$ wet mycelial paste.

\section{Products of the methyltransferase reaction}

The proteins in $10 \mu 1$ aliquots of CMT purified through the Mono Q-Tris step were separated by non-denaturing PAGE (Fig. $3 a$ ). One major protein and a few other minor contaminating proteins were found in the active fraction. The segment of gel corresponding to the major protein (see arrow) was excised from adjacent lanes and used directly in assays for CMT activity. The reactions were carried out using ${ }^{14} \mathrm{C}$-AdoMet $\left(43 \mathrm{mCi} \mathrm{mmol}^{-1}\right)$ and carminomycin, carminomycinone, 13-dihydrocarminomycin and 13-dihydrocarminomycinone as the methylgroup-accepting substrates. The major protein from the Mono Q-Tris purification step methylated carminomycin and 13-dihydrocarminomycin but not their aglycone analogues, carminomycinone and 13-dihydrocarminomycinone, respectively (Fig. $3 b$ ). These results 

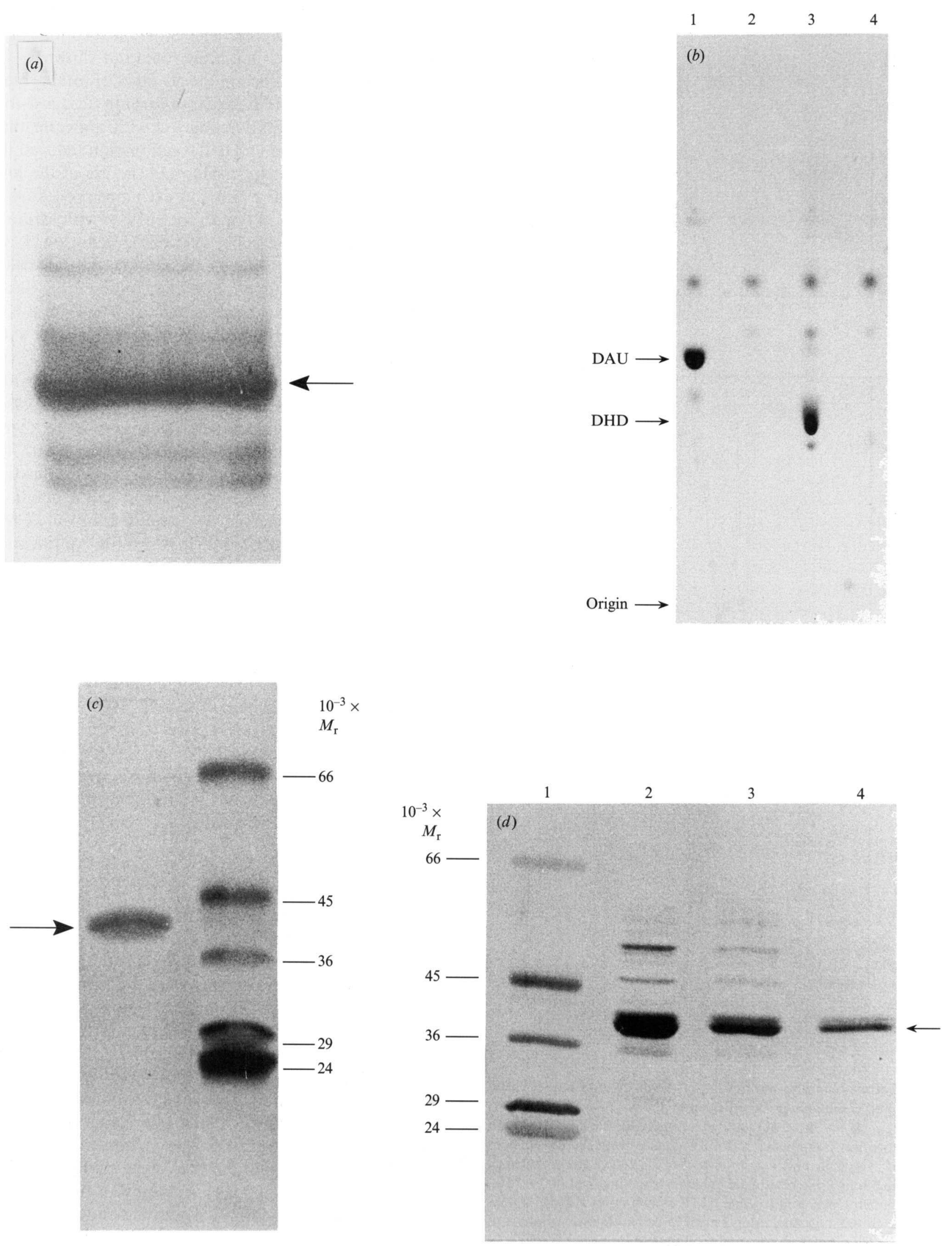
Table 2. Characteristics of CMT from Streptomyces sp. strain $C 5$

\begin{tabular}{lc}
\hline \hline$M_{\mathrm{r}}$ of native enzyme & 166000 \\
$M_{\mathrm{r}}$ of subunits & 41000 \\
Optimum pH for activity & $8 \cdot 0$ \\
Optimum temperature for activity & $37^{\circ} \mathrm{C}$ \\
Kinetics: & \\
$K_{\mathrm{m}}^{\prime}$ (carminomycin) & $0 \cdot 5 \mu \mathrm{M}$ \\
$K_{\mathrm{m}}^{\prime}(13$-dihydrocarminomycin) & $1 \cdot 0 \mu \mathrm{M}$ \\
$K_{\mathrm{m}}^{\prime}$ (AdoMet) & $25 \mu \mathrm{M}$ \\
Percentage inhibition* by: & 87 \\
AdoHcy $(25 \mu \mathrm{M})$ & 8 \\
Adenine $(250 \mu \mathrm{M})$ & 6 \\
Methionine $(250 \mu \mathrm{M})$ & $<5$ \\
Homocysteine $(250 \mu \mathrm{M})$ & $<5$ \\
Adenosine $(250 \mu \mathrm{M})$ & $<5$ \\
$\varepsilon$-Rhodomycinone $(10 \mu \mathrm{M})$ & $<5$ \\
Daunomycinone $(10 \mu \mathrm{M})$ & $<5$ \\
Daunomycin $(10 \mu \mathrm{M})$ & \\
\hline \hline
\end{tabular}

* Values are rounded off to integers. These data represent the mean of two determinations. The control reaction (without inhibitor) had an

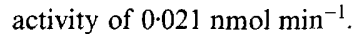

agree with the previous findings using crude cell extracts (Connors et al., 1990b). None of the other proteins, when excised from the gel and used in the assay, were capable of catalysing the methylation of carminomycin (data not shown). A control gel slice of similar size, from an area of the gel in which no proteins were present, also did not catalyse the methylation of carminomycin (data not shown). While non-denaturing PAGE proved useful to distinguish which protein contained CMT activity, loss in yield precluded its use as a purification step.

The products of the reaction catalysed by Mono Q-Tris-purified CMT were analysed by MS-MS to confirm the site of methylation. Authentic carminomycin $\left(M_{\mathrm{r}} 513.52\right)$ yielded an $\mathrm{M}+1$ of 514.1 and authentic daunomycin $\left(M_{\mathrm{r}} 527.51\right)$ yielded an $\mathrm{M}+1$ of 528.1 and major fragmentation species of $399 \cdot 0,381 \cdot 0,363 \cdot 0,321 \cdot 0$ and 130.0. After incubation of carminomycin for $1 \mathrm{~h}$ with enzyme purified through the Mono Q-Tris step, the extracted products observed in the parent MS included two major species, a peak with an $M+1$ of 514.1 (the substrate, carminomycin) and a peak with an $M+1$ of $528 \cdot 1$. The daughter spectrum from the $528 \cdot 1$ peak contained an $\mathrm{M}+1$ of 527.8 and major fragmentation species of $398 \cdot 7,380 \cdot 7,362 \cdot 7,320 \cdot 9$ and $129 \cdot 8$, identical to the fragmentation pattern observed with authentic daunomycin. This indicates that the methylation catalysed by highly purified CMT occurred at the 4-O position as predicted from the TLC results shown in Fig. 3(b).

\section{Determination of native and subunit $M_{r}$ of $C M T$}

Partially purified CMT (through DEAE-Sepharose) and a calibrated Superose 6 FPLC gel filtration column were used to determine the $M_{\mathrm{r}}$ of the native CMT. Peak activity appeared at an elution volume corresponding to a protein with $M_{\mathrm{r}}$ of approximately 166000 (data not shown). The major protein obtained from nondenaturing PAGE (Fig. 3a), shown previously to be enzymically active CMT (Fig. $3 b$ ), was eluted from the gel slice by passive diffusion into assay buffer and subjected to SDS-PAGE. The resultant single polypeptide had a $M_{\mathrm{r}}$ of approximately 41000 (Fig. $3 c$ ). This can be compared to an SDS-PAGE analysis of the proteins present in the Mono Q-Tris-purified fraction (Fig. $3 d$ ). Since SDS-PAGE analysis is more precise than gel-filtration for determining $M_{\mathrm{r}}$, the results suggest that native CMT is likely to be a homotetrameric protein of approximate $M_{\mathrm{r}} 164000$, composed of subunits of approximate $M_{\mathrm{r}} 41000$.

\section{Kinetics and inhibition of Streptomyces sp. strain C5 CMT}

Apparent $K_{\mathrm{m}}\left(K_{\mathrm{m}}^{\prime}\right)$ values for AdoMet, carminomycin and 13-dihydrocarminomycin were estimated to be $25 \mu \mathrm{M}, 0.5 \mu \mathrm{M}$ and $1.0 \mu \mathrm{M}$ (Table 2). Methionine and adenine showed very weak inhibitory activity $(6 \%$ and $8 \%$, respectively, compared to the control reaction) at $250 \mu \mathrm{M}$ concentrations. Neither L-homocysteine, adenosine, adenine, daunomycin, daunomycinone nor $\varepsilon$ rhodomycinone inhibited CMT activity at the concentrations used. At a concentration of $25 \mu \mathrm{M}, 10$-fold below the concentration of AdoMet used in the assay and roughly equal to the $K_{\mathrm{m}}^{\prime}$ for AdoMet, AdoHcy, a known

Fig. 3. Electrophoresis and activity of the methyltransferase. Experimental conditions were as described in Methods. (a) A $6 \%$ nondenaturing PAGE of proteins present after Mono Q-Tris step. The arrow indicates the major band excised from adjacent lanes and shown to catalyse the methylation of carminomycin and 13-dihydrocarminomycin. (b) Autoradiogram of $\left[{ }^{14} \mathrm{C}\right]$ methylated products formed by protein of the major band shown by the arrow in $(a)$. Lanes: 1 , carminomycin substrate; 2 , carminomycinone substrate; 3 , 13-dihydrocarminomycin substrate; 4, 13-dihydrocarminomycinone substrate. The major products formed in the reactions were $\left[{ }^{14} \mathrm{C}\right]$ daunomycin (DAU) and $13-\left[{ }^{14} \mathrm{C}\right]$ dihydrodaunomycin (DHD). (c) SDS-PAGE of the major protein isolated from $6 \%$ native gel shown by the arrow in $(a)$. Size standards used were: bovine serum albumin (66000), ovalbumin (45000), rabbit muscle glyceraldehyde3-phosphate dehydrogenase (36000), bovine erythrocyte carbonic anhydrase (29000), and bovine pancrease trypsinogen (24000). (d) SDS-PAGE of the proteins in the most active fraction from the Mono Q-Tris purification step. Lane 1 contains size standards (as in c). Lanes 2,3 and 4 contain $3.8 \mu \mathrm{g}, 1.9 \mu \mathrm{g}$ and $0.95 \mu \mathrm{g}$ protein, respectively. The protein presumed to be CMT is indicated by the arrow. 
inhibitor for methyltransferases (Zollner, 1990), inhibited CMT activity by $87 \%$.

\section{Discussion}

Under stabilizing conditions (i.e. in the presence of $1 \mathrm{~mm}$-DTT and $10 \%$ glycerol), an ammonium-sulphateprecipitated concentrate of the enzyme responsible for converting carminomycin to daunomycin (CMT) has been partially purified 114 -fold in a $5 \%$ yield by a sixstep procedure. CMT appeared to be purified approximately fourfold from crude, clarified extracts by the ammonium sulphate fractionation step. Thus, our purification protocol resulted in an approximate 400 -fold overall purification.

The resolution of two active fractions of CMT with the same specific activity after the first Mono Q HR 5/5 anion-exchange step is intriguing since these fractions behaved identically at every other chromatographic step. The minor species may be a derivative of the major species. Alternatively, the minor form of CMT may represent an isoenzyme of the major form. StutzmanEngwall \& Hutchinson (1989) isolated four non-overlapping clusters of anthracycline biosynthesis DNA from Streptomyces peucetius by heterologous hybridization using the actI (actinorhodin polyketide synthase) gene from Streptomyces coelicolor. While only cluster IV coded for the heterologous synthesis of daunomycin in Streptomyces lividans (Otten et al., 1990), the possibility that the other clusters code for at least some functional enzymes in the daunomycin biosynthesis pathway (of which CMT might be one) has never been ruled out. Unfortunately, the minor CMT species could not be recovered in sufficient amounts to determine what structural or kinetic differences distinguish it from the major species.

The properties of CMT are summarized in Table 2. As with methyltransferases involved in other antibiotic biosynthesis pathways (Rao et al., 1969; Corcoran, 1975; Speedie et al., 1975), the enzyme is optimally active at about $\mathrm{pH} 8.0$ and $37^{\circ} \mathrm{C}$. CMT has no apparent divalent cation requirement. Similarly, $O$-demethylpuromycin methyltransferase (Rao et al., 1969; Pogell, 1975), indolpyruvate $C$-methyltransferase (Speedie et al., 1975) and 3-hydroxyanthranilic acid methyltransferase (Fawaz \& Jones, 1988) did not have apparent requirements for divalent cations. On the other hand, demethylmacrocin $O$-methyltransferase and macrocin $O$-methyltransferase, isolated from the tylosin producer, Streptomyces fradiae, require $\mathrm{Mg}^{2+}$ plus $\mathrm{Mn}^{2+}$, and $\mathrm{Mg}^{2+}$ plus $\mathrm{Co}^{2+}$, respectively, for activity (Bauer et al., 1988; Kreuzman et al., 1988).

According to our data, Streptomyces sp. strain C5 CMT has an approximate $M_{\mathrm{r}}$ of 164000 and a subunit size of about 41000 ; therefore, the enzyme should be a tetramer with an $\alpha_{4}$ structure. A gene believed to encode the CMT from $S$. peucetius, another daunomycinproducing strain, has recently been sequenced and the deduced protein from that sequence has a $M_{\mathrm{r}}$ of 38782 (C. R. Hutchinson, personal communication). The $O$ demethylpuromycin $O$-methyltransferase isolated from Streptomyces alboniger is a homotetramer of subunits with $M_{\mathrm{r}} 40303$ (Rao et al., 1969; Lacalle et al., 1991). Other methyltransferases involved in antibiotic biosynthesis have different structures. For example, 3-hydroxyanthranilic acid methyltransferase (actinomycin biosynthesis) is a monomer with $M_{\mathrm{r}} 36000$ (Fawaz \& Jones, 1988), erythromycin $C$ methyltransferase has a monomeric $M_{\mathrm{r}}$ of 33900 , calculated from the deduced amino acid sequence (Haydock et al., 1991; the size of the native enzyme has not been published), and macrocin methyltransferase and demethylmacrocin methyltransferase (tylosin biosynthesis) are $\alpha_{2}$ and $\alpha_{3}$ proteins with subunits of 32000 and 42000, respectively (Kreuzman et al., 1988).

We previously showed that incubation of carminomycin and ${ }^{14} \mathrm{C}$-AdoMet with desalted cell extracts from several different daunomycin-producing streptomycetes resulted in the formation of ${ }^{14} \mathrm{C}$-daunomycin (Connors et al., 1990 b). 13-Dihydrocarminomycin, but no other glycones or aglycones tested, was an alternative substrate. Several lines of evidence suggest that CMT is the terminal enzyme in daunomycin biosynthesis. As previously stated (Connors et al., 1990b), these data also imply that organisms accumulating carminomycin (Brazhnikova et al., 1974) differ from daunomycinproducing strains simply in lacking 4- $O$-methyltransferase activity. Other methyltransferases that catalyse terminal reactions in antibiotic biosynthesis pathways include $O$-demethylpuromycin methyltransferase (Rao et al., 1969; Pogell, 1975), macrocin methyltransferase (Bauer et al., 1988), and erythromycin C methyltransferase (Corcoran, 1975).

There are examples of other methyltransferases catalysing parallel reactions comparable to the methylation of both carminomycin and 13-dihydrocarminomycin, in other secondary metabolic pathways. For example, demethylmacrocin methyltransferase and macrocin methyltransferase also methylate the demycarosyl analogues of their substrates, demethyllactenocin and lactenocin, respectively, albeit with slightly lower efficiencies (Bauer et al., 1988; Kreuzman et al., 1988). Also, two methyltransferases involved in aflatoxin production catalysed the methylation of primary substrate analogues (Yabe et al., 1989).

The $K_{\mathrm{m}}^{\prime}$ of CMT for AdoMet $(25 \mu \mathrm{M})$ is nearly the same as that of macrocin methyltransferase $(23 \mu \mathrm{M}$; Bauer et al., 1988), is slightly higher than those of 
indolepyruvate $C$-methyltransferase $(12 \mu \mathrm{M}$; Speedie et $a l ., 1975)$ and $O$-demethylpuromycin methyltransferase (10 $\mu \mathrm{M}$; Rao et al., 1969; Pogell, 1975), and is significantly lower than those of demethylmacrocin methyltransferase $(111 \mu \mathrm{M}$; Kreuzman et al., 1988) and 3hydroxyanthranilic acid methyltransferase $(180 \mu \mathrm{M}$; Fawaz \& Jones, 1988). The kinetic data indicate that CMT has a higher affinity for carminomycin $(0.5 \mu \mathrm{M})$ than for 13-dihydrocarminomycin $(1.0 \mu \mathrm{M})$ (Table 2). Considering that the rates of daunomycin production by Streptomyces sp. strain $\mathrm{C} 5$ are in the range of 1-10 pmol $\mathrm{l}^{-1} \mathrm{~h}^{-1}$ (W. R. Strohl, unpublished), the intracellular concentrations are probably much lower than these $K_{\mathrm{m}}^{\prime}$ values. This suggests that in vivo the conversion of carminomycin to daunomycin would be slightly favoured. Both of these kinetic constants are considerably lower than those observed for the methylrecipient substrates of other methyltransferases in secondary metabolite pathways. For examples, the $K_{\mathrm{m}}^{\prime}$ values for 3-hydroxyanthranilic acid, $O$-demethylpuromycin, demethylmacrocin and macrocin by their respective methyltransferases are $640 \mu \mathrm{M}$ (Fawaz \& Jones, 1988), $210 \mu \mathrm{M}$ (Rao et al., 1969; Pogell, 1975), $6 \mu \mathrm{M}$ (Kreuzman et al., 1988) and $5 \mu \mathrm{M}$ (Bauer et al., 1988). The $K_{\mathrm{m}}^{\prime}$ values for carminomycin and 13-dihydrocarminomycin seem to reflect accurately the low concentrations of daunomycin produced by Streptomyces sp. strain C5 (McGuire et al., 1980; Bartel et al., 1990).

AdoHcy, which strongly inhibits AdoMet-dependent methyltransferases (Zollner, 1990), is, as expected, a potent inhibitor of CMT. However, it is interesting to note that while requiring AdoMet as a methyl group donor, macrocin $O$-methyltransferase from Streptomyces fradiae is only weakly inhibited by AdoHcy (Bauer et al., 1988). The intracellular levels of AdoMet in Streptomyces sp. strain C5 are unknown but it has been suggested that methylation reactions are rate limiting in the biosynthesis of erythromycins and that the intracellular AdoMet:AdoHcy ratio may be important in regulating the formation of erythromycin A (Corcoran, 1975).

In Streptomyces sp. strain C5 fermentations, very little daunomycin is actually produced; $\varepsilon$-rhodomycinone, a known intermediate, is the major metabolite accumulated (McGuire et al., 1980; Bartel et al., 1990). The fact that CMT activity in crude cell extracts is below the limits of detection correlates with the low daunomycin titres obtained. The lack of inhibition by $\varepsilon$-rhodomycinone is significant from the perspective that this major anthracycline metabolite does not play a feed-forward regulatory role. The lack of inhibition by daunomycin and daunomycinone, products of methylation and of methylation followed by deglycosylation (Connors et al., $1990 \mathrm{~b}$ ), respectively, indicate that there is no feedback inhibition of the enzyme. In tylosin biosynthesis, the two methylation reactions are inhibited by both precursors and products of the reactions (Bauer et al., 1988; Kreuzman et al., 1988). The potential for an inhibitor of CMT activity (apparently removed after DEAE-Sepharose chromatography) is intriguing in that it may be a partial explanation for the very low levels of daunomycin accumulated. At this early stage, the nature of this inhibitor and the type of inhibition pattern it displays are not known.

We sincerely thank J. Lunel of Rhône-Poulenc, Inc., for authentic samples of carminomycin and 13-dihydrocarminomycin and we thank Adria, Inc., and the Frederick Cancer Research Center for additional authentic anthracycline and anthracyclinone samples. We are also deeply indebted to Professor Heinz G. Floss and Dr Ulla Mocek for running the MS-MS analysis of the reaction products of the methyltransferase reaction. We thank the OSU Fermentation Facility for use of the fermenters. This work was supported by the National Science Foundation under no. DMB-90-19585.

\section{References}

Bartel, P. L., Connors, N. C. \& Strohl, W. R. (1990). Biosynthesis of anthracyclines: analysis of mutants of Streptomyces sp. strain C5 blocked in daunomycin production. Journal of General Microbiology 136, 1877-1886.

Bauer, N. J., Kreuzman, A. J., Dotzlaf, J. E. \& Yeh, W.-K. (1988). Purification, characterization, and kinetic mechanism of $S$-adenosylL-methionine:macrocin $O$-methyltransferase from Streptomyces fradiae. Journal of Biological Chemistry 263, 15619-15625.

BRADFORD, M. M. (1976). A rapid and sensitive method for quantitation of microgram quantities of protein utilizing the principle of protein-dye binding. Analytical Biochemistry 72, 248-254.

Brazhnikova, M. G., Abarsky, V. B., Ponomarenko, V. I. \& PotaPOVA, N. P. (1974). Physical and chemical characteristics and structure of carminomycin, a new antitumor antibiotic. Journal of Antibiotics 27, 254-259.

Connors, N. C., BARtel, P. L. \& Strohl, W. R. (1990a). Biosynthesis of anthracyclines: enzymic conversion of aklanonic acid to aklavinone and $\varepsilon$-rhodomycinone by anthracycline-producing streptomycetes. Journal of General Microbiology 136, 1887-1894.

Connors, N. C., Bartel, P. L. \& Strohl, W. R. (1990 b). Biosynthesis of anthracyclines: carminomycin 4- $O$-methyltransferase, the terminal enzymic step in the formation of daunomycin. Journal of General Microbiology 136, 1895-1898.

CorCoRAN, J. W. (1975). S-Adenosyl-L-methionine:erythromycin $O$ methyltransferase. Methods in Enzymology 43, 487-498.

Dekleva, M. L., Titus, J. A. \& Strohl, W. R. (1985). Nutrient effects on anthracycline production by Streptomyces peucetius in a defined medium. Canadian Journal of Microbiology 31, 287-294.

ECKARDT, K. \& WAGNER, C. (1988). Biosynthesis of anthracyclinones. Journal of Basic Microbiology 28, 137-144.

FawaZ, F. \& Jones, G. H. (1988). Actinomycin synthesis in Streptomyces antibioticus. Purification and properties of a 3-hydroxyanthranilate 4-methyltransferase. Journal of Biological Chemistry 263, $4602-4606$.

Haydock, S. F., Dowson, J. A., Dhillon, N., Roberts, G. A., CORTES, J. \& Leadlay, P. F. (1991). Cloning and sequence analysis of genes involved in erythromycin biosynthesis in Saccharopolyspora erythraea: sequence similarities between EryG and a family of $S$ adenosylmethionine-dependent methyltransferases. Molecular and General Genetics 230, 120-128.

Kreuzman, A. J., Turner, J. R. \& Yeh, W.-K. (1988). Two distinctive $O$-methyltransferases catalyzing penultimate and terminal reactions of macrolide antibiotic (tylosin) biosynthesis. Substrate specificity, enzyme inhibition, and kinetic mechanism. Journal of Biological Chemistry 263, 15626-15633. 
LaCalle, R. A., Ruiz, D. \& JimÉnez, A. (1991). Molecular analysis of the $d m p M$ gene encoding an $O$-demethyl puromycin $O$-methyltransferase from Streptomyces alboniger. Gene 109, 55-61.

LAEMMLI, U. K. (1970). Cleavage of structural proteins during the assembly of the head of bacteriophage T4. Nature, London 227, 680-685.

McGuire, J. C., Thomas, M. C., Stroshane, R. M., Hamilton, B. K. \& WHITE, R. J. (1980). Biosynthesis of daunorubicin glycosides: role of $\varepsilon$-rhodomycinone. Antimicrobial Agents and Chemotherapy 18, 454-464.

MoRRISSEY, J. H. (1981). Silver stain for proteins in polyacrylamide gels: a modified procedure with enhanced uniform sensitivity. Analytical Biochemistry 117, 307-310.

Otten, S. L., Stutzman-Engwall, K. J. \& Hutchinson, C. R. (1990). Cloning and expression of daunorubicin biosynthesis genes from Streptomyces peucetius and $S$. peucetius subsp. caesius. Journal of Bacteriology 172, 3427-3434.

Pogell, B. M. (1975). S-Adenosyl-L-methionine: $O$-demethylpuromycin $O$-methyltransferase. Methods in Enzymology 43, 508-515.

PoHL, T. (1990). Concentration of proteins and removal of solutes. Methods in Enzymology 182, 68-83.

RaO, M. M., Rebello, P. F. \& Pogell, B. M. (1969). Biosynthesis of puromycin in Streptomyces alboniger: enzymatic methylation of $O$ demethylpuromycin. Journal of Biological Chemistry 244, 112-118.
Speedie, M. K., Hornemann, U. \& Floss, H. G. (1975). S-AdenosylL-methionine:indolepyruvate 3-methyltransferase. Methods in Enzymology 75, 498-502.

STroHL, W. R. \& ConNors, N. C. (1992). Significance of anthraquinone formation resulting from the cloning of actinorhodin genes in heterologous streptomycetes. Molecular Microbiology 6, 147-152.

Stutzman-Engwall, K. J. \& Hutchinson, C. R. (1989). Multigene families for anthracycline antibiotic production in Streptomyces peucetius. Proceedings of the National Academy of Sciences of the United States of America 86, 3135-3139.

Thompson, M. W., STrohl, W. R. \& Floss, H. G. (1992). Purification and characterization of TDP-D-glucose 4,6-dehydratase from anthracycline producing streptomycetes. Journal of General Microbiology 138, 779-786.

VARA, J. A. \& Hutchinson, C. R. (1988). Purification of thymidinediphospho-D-glucose 4,6-dehydratase from an erythromycin-producing strain of Saccharopolyspora erythraea by high resolution liquid chromatography. Journal of Biological Chemistry 263, 14992-14995.

Yabe, K., Ando, Y., Hashimoto, J. \& Hamasaki, T. (1989). Two distinct $O$-methyltransferases in aflatoxin biosynthesis. Applied and Environmental Microbiology 55, 2172-2177.

ZollneR, H. (1990). Handbook of Enzyme Inhibitors. New York: VCH Publishers. 